\title{
On the Application of Interactive College English Syllabus
}

\author{
Yao Luo \\ Eastern International Art College \\ Zhengzhou University of Light Industry \\ Zhengzhou, China 451450
}

\begin{abstract}
College English syllabus has been revised for seven times. It nationally reflects the significance of college English course. The 7th college English syllabus embodies the current national demand for talents, and also indicates the direction of college English teaching. On the base of the latest college English syllabus, this paper outlines the understanding deviation of status quo of college English syllabus, and puts forward the corresponding suggestions and measures, through modern foreign language theory.
\end{abstract}

Keywords-college english syllabus; interactive college english syllabus; interactivity

\section{INTRODUCTION}

In the educational field, whether it is student, parent, teacher, educational manager, and the educational polity maker, they must be familiar with the word of syllabus. In which, some even participate in the making and revision of the syllabus. Till now, China has formulated 7 syllabuses for English teaching in the state macro level. Each syllabus has advanced with the times not only in terms of contents but also in aspects such as teaching objective, teaching concept, teaching method and evaluation. And the term of syllabus has had different demarcation. The college English syllabus revised in 2004 and enforced formally in 2007, was renamed as "Course requirements of college English" (briefed as the "course requirements" hereafter)." The syllabus is one of the very important auxiliary teaching documents in the process for each college to enforce the college English teaching. The making of the syllabus must be done based on the "course requirement", and in combination with the factors such as the actual teaching plan, period of schooling and teaching hours. It regulates the arrangement of teaching contents and homework assignment of the teachers, to be the programmatic document for guiding the teachers teaching. The content of college English syllabus is similar and its requirement is basically similar too.

Making of the syllabus not only has guiding action for the teaching of teachers, but also is used for conducting inspection and supervision on the teaching of teachers according to the content of syllabus by the teaching management sector, and selection of the content of the syllabus embodies the direction of talent training by the colleges. Additionally, the syllabus has more actual guiding and directive nature for the main body persons of studying, the students. It has made clear specifications for the teaching content and requirements, teaching objectives of teachers for each semester with the assistance of the textbook and teaching calendar of college English course. Students can identify even clearly the task of their own by acknowledging and reading the above teaching documents. Teachers can help students to make out their own study plan by timely guide, to train their good learning habits accordingly.

According to the distinguishing of curriculum and syllabus by Tyler (1949) and Stern (1992), the "course requirement" stipulated by Ministry of Education is not compulsive, only has guiding functions for the teaching of college English. The "course requirement" has raised clearly that "to make scientific, systemic and personalized syllabus of college English for guiding the college English teaching of their own college". Wang Haixiao (2004) formulated a structural chart to illustrate the relations between the "course requirement", the syllabus of the college and the syllabus of the college English course. This paper aims to comb the current condition faced by the syllabus at the layer of course. By using the modern science and technology, and guided by the interactive theory, the paper makes some proposal and raises some measures for fully utilizing the syllabus of the college English, hoping to make people set up the teaching views of college English of student oriented.

\section{CURRENT CONDITIONS}

Restricted by the historical reason and actual conditions, the teachers' team of college is young generally, with no enough theory of education and teaching stored. The teaching managers paying attentions only on the current teaching effect, together with other reason on aspects of determination for college teaching reform and so on, have made the college English syllabus at the course level not be observed as it should be. By investigating the syllabus document of some colleges and interviewing the course teacher and syllabus compiling teacher, the compilation and use of the syllabus are mainly embodied in the following aspects: 1) The uniqueness of the syllabus. Whether it is for the department or the teaching research office, there is only one syllabus at the course level, and there is no macro teaching planning at the college level. Even for the making of the syllabus at the course level, the people composition for its making is mostly from teachers who teach in the English 
course, and their job title and education and teaching ability are not enough. Still, they did not make investigation and discussion for enough times, and lacked of communication with experts and subject leaders in the subject, resulting in frequent happening of work behind the closed doors. 2) The content of syllabus is old. In terms of content, the syllabus stays in listing of the knowledge points of the textbook, and determination of key and difficult points did not conform to the actual English level of students. It only makes design and selection of contents at the course layer, with rare considering of the current studying level of students, the studying motives of students, their studying habit and internalization level of learning, or only chooses the contents which the course teacher is good at, with the making of syllabus contents decided by the knowledge level and personal feature of the teachers. Sometimes, the teachers did not teach according to the syllabus, making it not be used for teaching and just for dealing with inspection. 3) Some teachers did not prepare lesions according to the syllabus. Even for the same lesson, the teachers did not teach that they should do, or they only teach on contents that they think to be important and difficult. 4) Lack of guide of the syllabus. The course teacher did not acknowledge the guiding role of the syllabus, and the guide to the learning of students, which result in students receiving the contents that teachers teach passively, having no way to really satisfy the students' learning needs. As the main participant of the teaching activity and the main body of learning, the student did not have chances to contact the syllabus of the subject at all, which makes students have no clear studying target and have no corresponding reference for the requirement to their own.

\section{THEORETICAL BASIS AND MEASURES}

The syllabus in the course layer has basis on both reality and theory. Hu Zhuanglin and others pointed out (1988), before making the syllabus, the practical problem for both the learner and teacher shall be researched. As the maker of the syllabus, he or she must have deep understanding for both students and teachers, before the syllabus can be made to conform to the students' learning level and teachers' teaching ability in aspects of the teaching target, course design and teaching evaluation and so on. Theoretical methods include input and output theory and interaction theory. According to the input theory of Krashen (1980), only when students contact with lots of understandable input, learning can be realized; while the best input condition is the input of language skill that is a little higher than the current skill of students. Meanwhile, the understandable output raised by Swain (1985) thinks that, the learner needs to have certain chances of "compulsory language expression", for making hyposis and verification of the meaning and structure of the target language. The learner shall not only observe the difference between what he or she tries to express and what the actual expression is, but also have changes to be aware of the assumption that he or she makes on the features of a certain kind of language, which is an important part for language learning. In addition, interaction is also a kind of communication, conforming to the theory of communicative teaching method. The interaction here refers to the relation of the teacher, student and syllabus. By communication, teachers know what they should teach, when they should teach and how to teach, and the students know what they should learn, how to learn and what the specific requirement is, to further form a contract spirit.

The multiple intelligence theory of Gardiner pointed out, "the intelligence of human being is multiple and not single. When teachers arrange the teaching activity in various phases of education, they shall cover the learning contents of multiple fields meanwhile, and use multiple teaching methods comprehensively, to provide studying situation conducive to the multiple intelligence development, letting various potential ability of each person obtain chances of full development. Every student is a unique individual, having uniqueness and nature of no replication. So, individualized teaching shall be used during the English course teaching. The individualized teaching of English refers to "teachers respect the individual value of each student in process of teaching, class and all the time and space of education, for developing its potential to the maximum, making students be able to make really effective communication in English according to their own behaviors and thoughts on precondition of observing the general rules." The individualized teaching emphasizes the equal status of teacher and student during the teaching activity. By interaction between teachers and students, and among students, the harmony and unity can be realized for the psychological logic and knowledge logic of students, for constructing a development process of spiral upgrading of English learning. During the teaching process, teachers shall use different teaching strategy and means to guide and enlighten the students to conduct autonomous English learning, make them promote their English skills gradually in continuous exploration and practice.

The interactive syllabus is to issue the printed syllabus to the student hands from the beginning of new semester, and make discussion on its content, activity arrangement and homework requirement and so on, for finally determining the specific contents of the syllabus, to ensure every student to understand it. This is equivalent to sign a contract between teachers and students, and both parties shall complete its own task according to its requirement. Such contract has been admitted by the students, being more able to ignite the activity and initiative of the students for learning. In fact, the interactive syllabus has a function similar to the teaching calendar. However, compared with the teaching calendar, the interactive syllabus is more specific and more flexible, easy to make timely adjust for individual according to the dynamic changes in the learning process of students, making the teaching content and task be a little more difficult than the actual level of students as possibly. According to the interactive syllabus, personal learning archive shall be set put for each student, to follow-up and investigate the students attending conditions to the class, record the routine performance of students and team work condition and so on. By using the interactive syllabus, the poor initiative of learning of students, lacking of internal learning motive, and being not positive to join in the class can be avoided. The not being positive of students can affect the teaching activeness of teachers indirectly, which will lower the sense of teachers' professional achievements, and make the occupation burnout 
happen too early. In view of this, to complain about the students' performance continuously has not benefit. By consultation with students, interactive syllabus can be made, letting each student have contents to learn, have his or her interests point, without requiring each student to reach the same level; meanwhile, teachers can observe the students closed by this way, for exploring the shining spot on the student, to enlarge the advantages of themselves and then make them willing to study English, not dislike it and expel it.

In terms of measures, it can be done mainly from the following several aspects:

1) Training the teaching manager and teachers, to master the principle and method for making the syllabus and interact with the outside. Breen (1987) thought that, the key for the syllabus design includes theoretical basis, core ability, teaching contents and order. Teachers may increase the theoretical knowledge by self studying and training, for knowing more about the teaching method of other countries in different stages and following up the latest researching results of second language learning. Among the teachers, they shall study the "course requirement" carefully, to feel the English teaching direction of the current stage, and read the papers of Wang Shouren, Dai Weidong, Cai Jigang, Xia Jimei and so on for knowing the general condition of foreign language teaching. Before making the syllabus, there are lots of work needed to do, especially the investigation on the learners and teachers. First is the condition of learners, including their learning attitude, the learning experience and habit in the past. Meanwhile, written and oral test shall be done for the learners, to know their current mastering and ability of the knowledge use, and the distance form the syllabus target and so on; second is to study the teachers, including the general condition of their actual knowledge level and application, and teaching experience and teaching habit and so on only on basis of investigation and research, we can know what to do next, how to arrange the content of syllabus, covering the teaching target, teaching principle, teaching method and textbook and evaluation means and so on.

2) Team cooperation for making the syllabus, with interaction with the team members. The making of the syllabus is not the thing of one person, and each course teacher shall have the responsibility and duty to share and contribute their own views and forces. After the completion of making of the syllabus, the leaders shall explain the process of making and problems encounters to all the teachers, together with the reason for choosing the content, striving to let each teacher know about all aspects of the syllabus, to make preparation for making the learning guide for the students. The making of the syllabus may refer to the course guide of other countries, especially the English course guide of the famous universities. The annex part of the guide can be added with requirement, resources and homework regarding listening, reading, writing, grammar and translation for trial use, for autonomous selection by students when forming their own learning guide.
3) Helping students to formulate their own learning guide, to interact with students. Compared with the syllabus for teachers teaching, the studying plan of students can be called as the studying guide temporarily. The process of the forming of the studying guide, first, students read the syllabus carefully, then consult with the teachers, to identify which task is not difficult enough, and which task may be deleted, on the precondition that teachers have acknowledged the learning level of students; Then, teachers makes out personal studying task archive of students, similar to the case written by the doctor, filed for regular review later. Finally, after the studying guide is enforced for a while, it shall be revised, and the part changed shall be recorded in the task list of students, as the standard for evaluation in the latter phase. the best method when surrounded by the mother's tongue is to create a good language environment and condition for students, by providing lots of proper learning materials of foreign language, and supplementing with explanation of necessary foreign language knowledge. Only by this way, the students' foreign language communication ability can be promoted faster and better.

4) Implementing the layering of the teaching target and teaching contents, to realize the interaction between the textbook and students. The layered teaching must abide by the principle of individualized teaching. The principle of individualized teaching refers that, the college English teachers shall perform the public English teaching with targets starting from the actual condition and individual difference of students, to make each student's personality and genius to get the best development on the original basis. The individualized teaching principle is to reflect the law of somatopsychic development. The somatopsychic development of college student has something in common, i.e. the feature of college students' ages, and also something individual, i.e. personality difference of college students, which require the English teaching shall consider not only the feature of age of college students, to make the depth and progress of college public English teaching suit to the knowledge level and receptivity of college students, but also the individual difference of college students, for individualized teaching.

\section{CONCLUSION}

Teaching of college English has close relation to the syllabus. Only after understanding the making flow process and basis of syllabus, better guide can be done for the students, to make out their own guide of learning. In this process, teacher and student have an equal, negotiating and cooperative relation. Teachers play the role of instructor, supervisor, helper and coach, and only students are the main body of learning. By the linking function of the syllabus and studying guide, to better handle the relation between teaching and learning is the aspiration of every teacher.

\section{REFERENCES}

[1] Breen M.P . Contemporary Paradigms in Syllabus Design [J] . Language Teaching, 1987(20) 
[2] Krashen, S.D. 1980. The input hypothesis. In J.E. Alatis (Ed.), Current issues on bilingual education (pp. 144-158). Washington, D.C.: TESOL.

[3] Krashen, S.D. 1981. Second Language Acquisition and Second Language Learning. Oxford: Pergamon.

[4] Krashen, S.D. 1982. Principles and Practices in Second Language Acquisition. New York: Pergamon.

[5] Stern, H. H. Issues and Options in Language Teaching [M]. Oxford: Oxford University Press, 1992.

[6] Swain, M. Communicative competence : Some roles of comprehensible input and comprehensible output in its development [A]. In S. Gass \& C. Madden(Eds.), Input in Second Language Acquisition[C].Rowley, MA : Newbury House, 1985.

[7] Tyler, R. Basic Principles of Curriculum and Instruction [M]. New York: Harcourt Brace, 1949.

[8] Hu Zhuanglin, Liu Yunqing, Li Yanfu, "Linguastics a course book" in 1988, Beijing: Peking University Press.

[9] Wang Haixiao, "Analysis on requirement and condition in the design of individualized English syllabus" [J], Foreign Language Education in China, 2004( 1). 